\title{
Extraction, Chemical Composition and Antioxidant Activity of Phenolic Compounds from Moroccan Satureja nepeta $L$.
}

\author{
A EZAOUINE *, M R SALAM,Y SBAOUI, B NOUADI, S ZOUHIR, M ELMESSAL, F CHEGDANI, F BENNIS
}

\section{A EZAOUINE *, M R SALAM,Y \\ SBAOUI, B NOUADI, S ZOUHIR, M \\ ELMESSAL, F CHEGDANI, F BENNIS}

Laboratory of Immunology and Biodiversity, Faculty of Sciences Ain Chock, Hassan II

University of Casablanca, Morocco

\section{Correspondence}

\section{A EZAOUINE}

Labortory of Immunology and Biodiversity, Departement of Biology, Faculty of

Sciences Aïn Chock, Hassan II University of Casablanca, Route El Jadida BP 5366 Maarif, Casablanca, Morocco

E-mail: ezaouine.abdelkarim@gmail.com History

- Submission Date: 10-11-2021.

- Review completed: 06-12-2021;

- Accepted Date: 13-12-2021.

DOI : 10.5530/pj.2022.14.24

Article Available online http://www.phcogj.com/v14/i1

\section{Copyright}

(C) 2022 Phcogj.Com. This is an openaccess article distributed under the terms of the Creative Commons Attribution 4.0 International license.

\section{ABSTRACT}

Satureja nepeta is an aromatic medicinal plant, widely used by the Moroccan population. The objective of this study is to evaluate the influence of extraction methods on total phenolic compounds (TPC) and total flavonoid compounds (TFC). The phytochemical characteristics are subsequently analyzed to determine the components constitution as well as the evaluation of antioxidant activity. The extraction optimization and the extraction of total polyphenols was carried out using three methods (decoction, infusion and hydroethanolic). The antioxidant capacity was evaluated using the DPPH free radical trapping method, reducing power assay and the ABTS radical reduction test. Polyphenols were identified by the HPLCUV method. The optimal hydro-ethanol extraction conditions defined from the experimental design are: ethanol/water, $60 / 40(\mathrm{v} / \mathrm{v}), 15$ hours, $42.5^{\circ} \mathrm{C}$ TPC and TFC of the infused extract were the highest. The evaluation of the antioxidant capacity showed that the infused extract had a good antioxidant efficacy. HPLC-UV and GC-MS has been used to identify some phenolic compounds in various extracts. In conclusion, optimizing the extraction of $S$. nepeta seems to be an efficient and quick method to establish the best extraction conditions. Also, Satureja.

Key words: Moroccan Satureja nepeta, Antioxidant activity, Total polyphenol, Total flavonoids, Total tannins.

\section{INTRODUCTION}

Aromatic and medicinal plants produce active compounds, secondary metabolites that have a pharmacological effect on living organisms. ${ }^{1}$ Many Moroccan plants of the Lamiaceae family have medicinal properties, they are a wide variety of phytochemical compounds (e.g. polyphenols, flavonoids and tannins) with antioxidant activity. In addition, there is a growing demand for herbal medicines. The genus Satureja belonging to the family of Lamiaceae, includes 200 species that are largely widespread in the Mediterranean, SouthWest Asia and America regions. ${ }^{2}$ The species Satureja nepeta is a small perennial plant that does not exceed $20 \mathrm{~cm}$ in height, plant with hairs, well leafed with large leaves and often at the top more or less rounded, between nodes is short. The flowering period is from July to November. ${ }^{3} S$. nepeta is an excellent medicinal plant that fights flatulence, stimulates digestion, and treats colic's. It has a "warming" effect and is recommended in case of respiratory tract infections. ${ }^{4}$

Several studies have been carried out worldwide on Satureja species by evaluating the effect of essential oil (EO), phenol acids, flavonoids and tannins on pharmacological activity, such as antimicrobial, insecticides, fungicides, antivirals and anti-inflammatories activities. ${ }^{5}$ To the best of our knowledge, no work has been carried out on endemic Moroccan S. nepeta.

Our study aims to identify the plant and to carry out a phytochemical study, including the determination of flavonoids and total phenols as well as the evaluation of the antioxidant activity in vitro of hydro-ethanolic, aqueous extracts and EO.

\section{MATERIALS AND METHODS}

\section{Chemical compounds and reagents}

Ethanol, Quercetin was supplied by China Institute for Drugs and Biological Products Identification (Beijing, China), and the purity is over $98 \%$. sodium carbonate, sodium nitrite, aluminum trichloride, anthrone, sulfuric acid, disodium phosphate FolinCiocalteu reagent and 1,1-diphenyl-2-picrylhydrazyl radical (DPPH), ABTS (2,2'-Azinobis-(3ethylbenzthiazoline-6-sulfonic acid), ferric chloride $\left(\mathrm{FeCl}_{3}\right)$ and Ascorbic acid were purchased from Sigma (St. Louis, MO, USA). All the other reagents were of analytical grade, methanol and Formic acid (HPLC grade) were obtained from Merck (Darmstadt, Germany), The phenolic standards (Protocatechuic acid, Protocatechuic aldehyde, p-Hydroxybenzoic acid, p-Hydroxybenzaldehyde, Vanillic acid, Catechin, Rutin, Caffeic acid, Syringic acid, Vanillin, p-Coumaric acid, Ferulic acid), Gallic acid.

\section{Plant identification}

To identify the plant, an herbarium sample was prepared and submitted to the laboratory of the Scientific Institute of Rabat, department of botany and ecology plant (http://www.israbat.ac.ma). The voucher specimen was deposited under reference 107337 , in the same Institute.

\section{Plant sampling and preparation}

S. nepeta L. plant was collected in March 2019, at the Oukaïmeden region (latitude $31^{\circ} 13^{\prime} 55.6$ "'" north/ longitude $7^{\circ} 49^{\prime} 56.0 \mathrm{w}$ ), on the Middle Atlas of Morocco. The aerial part of the fresh samples was air-dried in the shade, at room temperature, then stored in sealed paper bags until used for analysis.

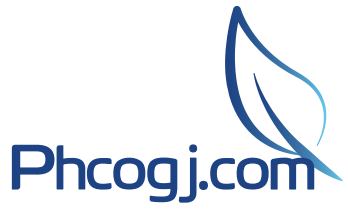

Cite this article: A EZAOUINE * M R SALAM, Y SBAOUI, B NOUADI, S ZOUHIR, M ELMESSAL, et al. Extraction, Chemical Composition and Antioxidant Activity of Phenolic Compounds from Moroccan Satureja nepeta L. Pharmacogn J. 2022;14(1): 182-192. 


\section{Experimental design for optimization of sample preparation and data analysis}

A Box-Behnken experimental design with three variables at three levels was used to determine the response pattern and the interaction effect of independent variables on the response. The three key variables namely extraction temperature (A), extraction time (B) and concentration of ethanol /water (C) were selected to optimize the hydroalcoholic extraction of TPC and TFC from the S. nepta L. plant. The analysis of the combined effect of these factors is performed through the Design Expert 8.0 software, a mathematical and statistical tool that is widely used to optimize the experimental conditions of the process. ${ }^{6}$ The results of the given experimental plan and validation of predicted values at optimal extraction conditions are shown in the table 1 and 2 .

\section{Response surface methodology}

\section{Experimental design for formulation optimization}

The effect of three independent factors were studied in order to optimize the extraction of phenolic compounds and flavonoids: extraction temperature $\left({ }^{\circ} \mathrm{C}\right)$, extraction time $(\mathrm{h})$, and ethanol/water (\%) were the three entries, which were coded on three levels: low (1), medium (0), and high (+1). The values chosen were based on the following preliminary research; the extraction temperature should be between 25 and $60{ }^{\circ} \mathrm{C}$, the time should be between 6 and 24 hours, and the ethanol concentration should be between 40 and $80 \%$. A boxBehnken design was applied because of its economy with respect to the number of experimental trials required. The selected design variables in this study are presented in table 1 with the actual and coded levels and response variables. The corresponding box Behnken design includes 12 trials, and 4 additional trials were included in the center of the design to assess pure error. All trials were run in random order. For each response variable, a full quadratic polynomial model was created by technical multiple regression to subsequently determine the optimal formulation that maximizes both responses: $\mathrm{y}=\mathrm{b} 0+\sum_{\mathrm{i}=1}^{\mathrm{n}} \mathrm{biXi}+\sum_{\mathrm{i}=1}^{\mathrm{n}} \mathrm{bii} \mathrm{X}_{\mathrm{I}}^{2}+\sum \sum_{\mathrm{i}<j=2}^{\mathrm{n}} \mathrm{bijXiXj}$

Where,

b0 was the constant coefficient or intercept.

bi were the first order linear coefficients.

bii were the quadratic coefficients.

bij (with $\mathrm{i} \neq \mathrm{j}$ ) were the second order interaction coefficients.

\section{Statistical analysis and response optimization}

To determine the consistency of the fitted quadratic models, an analysis of variance (ANOVA) was used by measuring the F value, the regression coefficients were assessed. The coefficient of determination, R2, as well as the model's and lack of fit's significance values, is determined to validate the model. The model must be statistically valid to a $95 \%$ confidence standard $(\mathrm{P}<0.05)$, and the loss of fit must be non-significant $(\mathrm{P} \geq 0.05)$ for it to be considered accurate. The optimal maximum responses were then determined by optimizing the three response variables, allowing for the same weighting for all three. This was achieved by using desirability function approach. ${ }^{7}$ Design Expert 8.0 software was used for data processing, ANOVA, and linear regression, as well as response optimization.

\section{Preparation of the hydroalcoholic extract, infusion and decoction}

The aerial part of $S$. nepeta L. was used for preparation of different extract namely hydroalcoholic extract, infusion and decoction. Hydroalcoholic extractions were performed by stirring the aerial part of plant (10 g of material) with $100 \mathrm{~mL}$ of ethanol/water 60:40 (v/v) at $42.5^{\circ} \mathrm{C}$ and filtered through Whatman $\mathrm{N}^{\circ} 3$ paper, the residue was then extracted with one additional $60 \mathrm{~mL}$ of the hydroalcoholic mixture. The combined extracts were evaporated at $45^{\circ} \mathrm{C}$. Infusion was prepared by the addition of $10 \mathrm{~g}$ dried materiel to $100 \mathrm{~mL}$ of boiling distilled water

\section{Table 1: Experimental data of the validation of predicted values at optimal extraction conditions.}

\begin{tabular}{|c|c|c|c|c|c|c|c|c|}
\hline \multicolumn{2}{|c|}{ Variable } & \multicolumn{2}{|c|}{ Units } & \multicolumn{5}{|c|}{ Variable levels } \\
\hline & & & & & \multicolumn{2}{|r|}{ Low $(-1)$} & \multirow{2}{*}{$\begin{array}{l}\text { Middle (0) } \\
\quad 42\end{array}$} & Hight $(+1)$ \\
\hline \multicolumn{2}{|c|}{ Extraction temperature } & \multicolumn{2}{|c|}{${ }^{\circ} \mathrm{C}$} & A & \multicolumn{2}{|r|}{25} & & 60 \\
\hline \multicolumn{2}{|c|}{ Extraction time } & \multicolumn{2}{|c|}{$\mathrm{h}$} & B & \multicolumn{2}{|r|}{6} & 15 & 24 \\
\hline \multicolumn{2}{|c|}{ Ethanol /water } & \multicolumn{2}{|c|}{$\%$} & $\mathrm{C}$ & \multicolumn{2}{|r|}{40} & 60 & 80 \\
\hline \multirow{3}{*}{ Std } & \multirow{3}{*}{ Run } & \multirow{3}{*}{$\begin{array}{c}\text { Factor } 1 \\
\text { A : temperature } \\
{ }^{\circ} \mathrm{C}\end{array}$} & Factor 2 & \multirow{3}{*}{$\begin{array}{c}\text { Factor } 3 \\
\text { C : eth/water } \\
\%\end{array}$} & \multirow{2}{*}{\multicolumn{2}{|c|}{$\begin{array}{c}\text { Response } 1 \\
\text { Phenolic content } \\
\text { (mg TAE/g extract) }\end{array}$}} & \multicolumn{2}{|c|}{ Response 2} \\
\hline & & & \multirow[t]{2}{*}{$\begin{array}{l}\mathrm{B}: \mathrm{time}_{\mathrm{h}} \\
\end{array}$} & & & & \multicolumn{2}{|c|}{$\begin{array}{l}\text { Flavonoid content } \\
\text { (mg QE/g extract) }\end{array}$} \\
\hline & & & & & Predicted value & Experimental value & Predicted value & Experimental value \\
\hline 13 & 1 & $42,5(0)$ & $15(0)$ & $60 \quad(0)$ & 33,96 & 34,11 & 13,36 & 13,73 \\
\hline 15 & 2 & $42,5(0)$ & $15(0)$ & $60(0)$ & 33,96 & 33,89 & 13,36 & 13,68 \\
\hline 10 & 3 & $42,5(0)$ & $24(+1)$ & $40(-1)$ & 27,34 & 28,14 & 9,11 & 8,17 \\
\hline 2 & 4 & $60(+1)$ & $6(-1)$ & $60(0)$ & 23,48 & 23,14 & 8,50 & 8,55 \\
\hline 4 & 5 & $60(+1)$ & $24(+1)$ & $60(0)$ & 28,70 & 28,39 & 8,35 & 8,39 \\
\hline 1 & 6 & $25(-1)$ & $6(-1)$ & $60(0)$ & 23,36 & 23,67 & 9,51 & 9,47 \\
\hline 8 & 7 & $60(+1)$ & $15(0)$ & $80(+1)$ & 29,82 & 30,97 & 9,14 & 8,16 \\
\hline 7 & 8 & $25(-1)$ & $15(0)$ & $80(+1)$ & 25,82 & 26,31 & 12,98 & 12,08 \\
\hline 14 & 9 & $42,5(0)$ & $15(0)$ & $60(0)$ & 33,96 & 34,16 & 13,36 & 13,63 \\
\hline 6 & 10 & $60(+1)$ & $15(0)$ & $40(-1)$ & 32,11 & 31,62 & 12,10 & 13 \\
\hline 5 & 11 & $25(-1)$ & $15(0)$ & $40(-1)$ & 27,32 & 26,17 & 9,97 & 10,95 \\
\hline 9 & 12 & $42,5(0)$ & $6(-1)$ & $40(-1)$ & 26,47 & 27,31 & 12,34 & 11,39 \\
\hline 11 & 13 & $42,5(0)$ & $6(-1)$ & $80(+1)$ & 24,49 & 23,69 & 9,43 & 10,37 \\
\hline 17 & 14 & $42,5(0)$ & $15(0)$ & $60(0)$ & 33,96 & 33,98 & 13,36 & 12,98 \\
\hline 3 & 15 & 25 & 24 & 60 & 20,03 & 20,37 & 9,05 & 9 \\
\hline 12 & 16 & 42,5 & 24 & 80 & 25,52 & 24,68 & 12,05 & 13 \\
\hline 16 & 17 & 42,5 & 15 & 60 & 33,96 & 33,68 & 13,36 & 12,76 \\
\hline
\end{tabular}


Table 2: Analysis of variance (ANOVA) for the experimental results.

\begin{tabular}{|c|c|c|c|c|c|c|c|c|c|c|}
\hline \multirow{2}{*}{ Source } & \multicolumn{5}{|c|}{$\begin{array}{l}\text { ANOVA for response surface quadratic model of phenolic } \\
\text { content extraction }\end{array}$} & \multicolumn{5}{|c|}{$\begin{array}{l}\text { ANOVA for response surface quadratic model of flavonoid content } \\
\text { extraction }\end{array}$} \\
\hline & $\begin{array}{l}\text { Sum of } \\
\text { Squares }\end{array}$ & $\begin{array}{l}\text { Degree of } \\
\text { freedom }\end{array}$ & Mean Square & F-value & p-value & $\begin{array}{l}\text { Sum of } \\
\text { Squares }\end{array}$ & $\begin{array}{l}\text { Degree of } \\
\text { freedom }\end{array}$ & Mean Square & F-value & p-value \\
\hline Model & 326,52 & 9 & 36,28 & 39,67 & $<0.0001$ & 65,30 & 9 & 7,26 & 6,43 & 0,0113 \\
\hline A-temperature & 38,72 & 1 & 38,72 & 42,34 & 0,0003 & 1,44 & 1 & 1,44 & 1,28 & 0,2951 \\
\hline B-time & 1,78 & 1 & 1,78 & 1,94 & 0,2060 & 0,1860 & 1 & 0,1860 & 0,1649 & 0,6969 \\
\hline C-eth/ water & 7,20 & 1 & 7,20 & 7,87 & 0,0263 & 0,0012 & 1 & 0,0012 & 0,0011 & 0,9744 \\
\hline $\mathrm{AB}$ & 18,28 & 1 & 18,28 & 19,98 & 0,0029 & 0,0240 & 1 & 0,0240 & 0,0213 & 0,8881 \\
\hline $\mathrm{AC}$ & 0,1560 & 1 & 0,1560 & 0,1706 & 0,6919 & 8,91 & 1 & 8,91 & 7,90 & 0,0262 \\
\hline $\mathrm{BC}$ & 0,0064 & 1 & 0,0064 & 0,0070 & 0,9357 & 8,56 & 1 & 8,56 & 7,58 & 0,0284 \\
\hline $\mathrm{A}^{2}$ & 55,47 & 1 & 55,47 & 60,65 & 0,0001 & 18,47 & 1 & 18,47 & 16,36 & 0,0049 \\
\hline $\mathrm{B}^{2}$ & 174,73 & 1 & 174,73 & 191,06 & $<0.0001$ & 24,44 & 1 & 24,44 & 21,66 & 0,0023 \\
\hline $\mathrm{C}^{2}$ & 10,34 & 1 & 10,34 & 11,30 & 0,0120 & 0,1933 & 1 & 0,1933 & 0,1713 & 0,6914 \\
\hline Residual & 6,40 & 7 & 0,9146 & & & 7,90 & 7 & 1,13 & & \\
\hline Lack of Fit & 6,26 & 3 & 2,09 & 57,08 & 0,0010 & 7,08 & 3 & 2,36 & 11,57 & 0,0193 \\
\hline Pure Error & 0,1461 & 4 & 0,0365 & & & 0,8165 & 4 & 0,2041 & & \\
\hline Cor Total & 332,92 & 16 & & & & 73,20 & 16 & & & \\
\hline \multicolumn{11}{|c|}{ Credibility analysis of the regression equations for phenolic } \\
\hline $\begin{array}{l}\text { Std. Dev. } \\
\quad 0.95\end{array}$ & $\begin{array}{l}\text { Mean } \\
28.49\end{array}$ & $\begin{array}{l}\text { C.V. } \% \\
3.36\end{array}$ & $\begin{array}{l}\text { Press } \\
100.32\end{array}$ & $\begin{array}{c}\mathrm{R}^{2} \\
0.98\end{array}$ & $\begin{array}{l}\text { Adjust } \mathrm{R}^{2} \\
0.95\end{array}$ & $\begin{array}{c}\text { Predicted } \mathrm{R}^{2} \\
0.69\end{array}$ & $\begin{array}{c}\text { Adequacy } \\
\text { precision } \\
19.00\end{array}$ & & & \\
\hline \multicolumn{11}{|c|}{ Credibility analysis of the regression equations for flavonoid } \\
\hline $\begin{array}{l}\text { Std. Dev. } \\
1.06\end{array}$ & $\begin{array}{l}\text { Mean } \\
11.14\end{array}$ & $\begin{array}{c}\text { C.V. \% } \\
9.54\end{array}$ & $\begin{array}{c}\text { Press } \\
114.61\end{array}$ & $\begin{array}{c}\mathrm{R}^{2} \\
0.89\end{array}$ & $\begin{array}{c}\text { Adjust } \mathrm{R}^{2} \\
0.85\end{array}$ & $\begin{array}{c}\text { Predicted } \mathrm{R}^{2} \\
0.56\end{array}$ & $\begin{array}{l}\text { Adequacy } \\
\text { precision } \\
6.14\end{array}$ & & & \\
\hline
\end{tabular}

and left to stand at room temperature for $5 \mathrm{~min}$ and then filtered under reduced pressure. For decoction, $10 \mathrm{~g}$ of dried material sample was added to $100 \mathrm{~mL}$ of distilled water, heated and boiled for $5 \mathrm{~min}$. The mixtures were left to stand for $5 \mathrm{~min}$. The lyophilized hydroalcoholic extract, infusion and decoction were re-dissolved in ethanol/water $60: 40(\mathrm{v} / \mathrm{v})$ and water respectively, to obtain a stock solution of $20 \mathrm{mg} / \mathrm{mL}$.

\section{Essential oil extraction}

The EO of S. nepeta L. was isolated from fresh plant material (100 g) by hydro distillation, for $4 \mathrm{~h}$, using a Clevenger-type apparatus according to the European pharmacopoeia method. ${ }^{8}$

\section{Analytical conditions for HPLC-UV}

Chemical composition of polyphenol extracted was analyzed by HPLC-UV method. ${ }^{9}$ Liquid chromatographic separation and quantification was performed on an Agilent 1260 HPLC system equipped with a membrane degasser, a binary pump, a standard autosampler, a thermostatted column compartment and a diode array detector. Phenolic compounds were separated on a BDS Hypersil C18 $(5 \mu \mathrm{m}, 150 \times 4.6 \mathrm{~mm})$ column (Phenomenex) thermostated at 40 ${ }^{\circ} \mathrm{C}$. Mobile phase A consisted of acetonitrile /water 5/95 (v/v). The solvent flow rate was $0.5 \mathrm{~mL} / \mathrm{min}$, the injection volume was $20 \mu \mathrm{L}$, and the column temperature was maintained at $40{ }^{\circ} \mathrm{C}$. Detection was carried out by measurement of the UV absorbance at $280 \mathrm{~nm}$ during $60 \mathrm{~min}$. An aqueous acetonitrile solvent system was always used in the HPLC analysis of phenolic acids (Liu et al., 2015). The identification of polyphenols was performed by comparison of the retention time of extracts with reference standard compound in published studies. HPLC-UV for the extracts was accomplished using the CNRST technic realized at the technic platform of CNRST, Rabat, Morocco.

\section{EO chemical composition determination}

GC-MS analysis of EO was performed using an Agilent $6890 \mathrm{~N}$ array GC system equipped with an Agilent-Technologies 5975 inert XL mass selective detector and an Agilent-Technologies 7683B series autoinjector (Agilent Technologies, Little Falls, CA, USA). Agilent Technologies column: DB5 MS: $30 \mathrm{~m}$ x $0.25 \mathrm{~mm}$, film thickness 0.25 $\mu \mathrm{m}$ was directly coupled to the MS. Chromatographic conditions were as follows: injection and detection temperatures were 280 and $300{ }^{\circ} \mathrm{C}$, respectively. The column temperature was programmed to increase from 50 to $300{ }^{\circ} \mathrm{C}$ at a rate of $5 \mathrm{~min}$. The lower and upper temperatures were held for 2 and $20 \mathrm{~min}$, respectively. Helium was used as the carrier gas at a flow rate of $1 \mathrm{ml} / \mathrm{min}$. A $10 \mu \mathrm{l}$ sample was injected using the fractionated mode (fractionation ratio: 1:20). For MS detection, electron ionization was used with an ionization energy of 70 $\mathrm{eV}$, and the $\mathrm{m} / \mathrm{z}$ scan range was from 35 to 450 . The identification of the components is based on the comparison of the retention times of each component, their mass spectra and their KI (Kovats index) with those of pure substances recorded in the literature, especially. ${ }^{12}$

\section{Determination of total polyphenol content}

The extracts TPC were determined using the Folin-Ciocalteau reagent with Gallic acid as standard solution as described. ${ }^{13}$ The extract sample $(0.5 \mathrm{~mL})$ and Gallic acid $(2-10 \mathrm{mg} / \mathrm{mL})$ were transferred to a $10 \mathrm{~mL}$ volumetric flask containing $6 \mathrm{~mL}$ of water, to which were subsequently added $500 \mu \mathrm{L}$ of undiluted Folin-Ciocalteu reagent; after $1 \mathrm{~min}, 1.5$ $\mathrm{mL}$ of $7.5 \%$ aqueous $\mathrm{Na}_{2} \mathrm{CO}_{3}$ were added, and the flask was brought to volume with water. After $30 \mathrm{~min}$ incubation at $25^{\circ} \mathrm{C}$, the absorbance was measured at $765 \mathrm{~nm}$ versus a blank prepared without extract. The TPC was expressed as mg Gallic acid equivalents (GAE)/g dry weight using the following equation based on the calibration curve: $y$ $=0,0073 \mathrm{x}\left(\mathrm{R}^{2}=0,9829\right)$, where $\mathrm{x}$ was the absorbance and $\mathrm{y}$ the Gallic acid concentration $(\mu \mathrm{g} / \mathrm{mL})$. Data presented are the average of three independent measurements, expressed in dry weights of leaves.

\section{Determination of total flavonoid content}

TFC of hydroalcoholic and aqueous extract (decoction and infusion) were quantified as described ${ }^{14}$ based on the formation of a complex 
flavonoid-aluminum. An amount of $0.5 \mathrm{~mL}$ of a $2 \% \mathrm{AlCl}_{3}$ ethanol solution was added to $0.5 \mathrm{~mL}$ of extract $(300 \mu \mathrm{g} / \mathrm{mL})$ and quercetin $(5-$ $120 \mu \mathrm{g} / \mathrm{mL}$ ). After $1 \mathrm{~h}$ at room temperature in the dark, the absorbance was measured at $420 \mathrm{~nm}$ versus a blank prepared without extract. The TFC was calculated as Quercetin ( $\mathrm{mg} / \mathrm{g}$ ) equivalents using the following equation based on the calibration curve: $y=0,0349 x\left(R^{2}=0,982\right)$ where $\mathrm{x}$ was the absorbance and $\mathrm{y}$ was the Quercetin concentration $(\mu \mathrm{g} / \mathrm{mL})$. Data presented are the average of three independent measurements, expressed in dry weights of leaves.

\section{Determination total tannin content}

The Folin-Ciocalteu method described ${ }^{15}$ was used to determine the tannin content in the concoctions. Briefly, $0.1 \mathrm{~mL}$ of the sample extract was added to a clean test tube containing $7.5 \mathrm{~mL}$ of distilled water. The Folin-Ciocalteu reagent $(0.5 \mathrm{~mL})$ was added to the mixture and vortexed. $1 \mathrm{~mL}$ of $35 \%$ solution of sodium carbonate $\left(\mathrm{Na}_{2} \mathrm{CO}_{3}\right)$ was added to mixture. The mixture in the tube was transferred to a $10 \mathrm{~mL}$ volumetric flask and the volume of the mixture was made up to $10 \mathrm{~mL}$ by distilled water. The mixture was shaken and kept at room temperature for $30 \mathrm{~min}$ in the dark. Gallic acid was used as a standard and reference standard solutions $(0.625-1 \mathrm{mg} / \mathrm{mL})$ were prepared. Absorbance for test and standard solutions were measured against the blank at $725 \mathrm{~nm}$ with an UV/Visible spectrophotometer. The estimation of the tannin content was carried out in triplicate. Tannin content was expressed as milligram gallic acid equivalence/gram of extract (mg GAE/g extract).

\section{Antioxidant activity}

\section{Reducing power assay}

Essentially, the Reducing power assay treats antioxidants in the sample as a reduction in calorimetry related to the oxidation-reduction reaction, the reducing power was measured according to ${ }^{16} \mathrm{~A}$ volume of $0.5 \mathrm{~mL}$ of sample was homogenized with $2.5 \mathrm{~mL}$ of phosphate buffer $(0.2 \mathrm{M}, \mathrm{pH} 6.6)$ and $2.5 \mathrm{~mL}$ of potassium ferricyanide $\left[\mathrm{K}_{3} \mathrm{Fe}(\mathrm{CN})_{6}\right]$ (1\%). After incubation in a water bath $\left(50{ }^{\circ} \mathrm{C} / 20 \mathrm{~min}\right), 2.5 \mathrm{~mL}$ of Trichloro Acetic Acid (10\%) was added to the mixture. The upper layer of the solution $(2.5 \mathrm{~mL})$ was mixed with distilled water $(2.5 \mathrm{~mL}) . \mathrm{EC}_{50}$ was calculated from the graph of absorbance at $700 \mathrm{~nm}$ against extract concentration in the solution. The higher the absorbance, the higher the antioxidant activity. Tests were carried out in triplicate. Ascorbic acid and BHT was used as positive control.

\section{Scavenging activity against $D P P H$ free radical}

The DPPH (2,2-diphenyl-1-picryl-hydrazyl-hydrate) radical scavenging capacity of $S$. nepta L. was determined by the method described. ${ }^{17}$ With modifications concerning the time of reaction, according to ${ }^{18}$ a methanolic stock solution $(50 \mu \mathrm{L})$ of each sample at different concentration was placed in a cuvette, and, $2 \mathrm{~mL}$ of $60 \mu \mathrm{M}$ methanolic solution of DPPH was added. Absorbance measurements were made at $517 \mathrm{~nm}$ using a spectrophotometer UV thermobiomate after $60 \mathrm{~min}$ of reaction at room temperature. The values of $\mathrm{IC}_{50}$ were determined as reported above. Tests were carried out in triplicate. Acid ascorbic and BHT was as positive control.

\section{Scavenging activity against ABTS free radical}

The ABTS (3-ethylbenzthiazoline-6-sulphonic acid) free radical scavenging assay was conducted as described by ${ }^{19}$ The ABTS radical cation was prepared by mixing equal volumes of $7 \mathrm{mM}$ ABTS solution and $2.5 \mathrm{mM}$ Potassium persulphate. The mixture was placed in the dark for $15 \mathrm{~h}$ at room temperature to obtain ABTS radical solution and then diluted with ethanol to an absorbance of $0.7 \pm 0.02$ units at $734 \mathrm{~nm}$, extracts $(0.2 \mathrm{~mL})$ or a reference substance $(0.2 \mathrm{~mL})$ were allowed to react with $2.8 \mathrm{~mL}$ of the ABTS solution for $30 \mathrm{~min}$ in the dark until a stable absorbance was obtained. The decrease of absorbance at 734 $\mathrm{nm}$ was measured by spectrophotometer UV thermo-biomate against a blank (Ethanol). Data for each assay were recorded in triplicate whilst all tests and data analysis were recorded, ascorbic acid and BHT were used for positive control. Antioxidant activity, as ABTS radicalscavenging capacity, was estimated, based on the percentage, by the following formula:

ABTS \% scavenging activity $(\%)=[($ A blank-A sample $) /$ A blank $] \times 100 \%$

Where, A blank is the absorbance of the control reaction (containing all reagents except the test compound), and A sample was the absorbance of the test compound.

\section{Statistical analyses}

Samples of $S$. nepeta extracts (decoction, infusion and hydroalcoholic) were prepared and analyzed in triplicates. The results, expressed as mean values and standard deviation (SD), were analyzed using oneway analysis of variance (ANOVA) followed by Tukev's HSD Test. Differences were considered significant at the level $\mathrm{p}<0.05$, the analysis was performed using prism 8 software for Windows (Graph Pad Software Inc., San Diego, CA, USA).

\section{RESULTS AND DISCUSSION}

The plant studied was first identified morphologically by the department of botany and ecology plant of the Scientific Institute of Rabat, Morocco, and deposited under reference 107337, in the same Institute. This is $S$. nepeta L., of which no study has been carried out until now.

\section{Effect of process variables on total phenolic and flavonoids content}

TPC and TFC obtained, in different conditions of extraction, are presented in table 1 . The contents of phenolic compounds of $S$. nepta L. varies from 20.37 to $34.11 \mathrm{mg}$ TAE/g extract, and for flavonoids varies between 8.16 to $13.73 \mathrm{mg} \mathrm{QE} / \mathrm{g}$ extract which confirms the influence of the parameters $(\mathrm{A}, \mathrm{B}$ and $\mathrm{C})$ on the rate of extraction that is demonstrated by several authors. ${ }^{20,21}$ Lower probability values ( $p<0.0001)$ mean that the model terms are significant, the statistical significance of the formulated regression models was high, as indicated by the $\mathrm{R}^{2}$ values. The appropriate precision value is a measure of the signal-to-noise ratio. A ratio $>4$ is desirable; ${ }^{22}$ in this study, the ratio for polyphenols is 19 and 6.16 for flavonoids, indicating an adequate signal and therefore the model is suitable for this process. The coefficient of variation $(\mathrm{CV})$ is a measure of the reproducibility of the model, and generally a model can be reproducible if the coefficient of variation is $<10 \%$. The CV measure in our study, is $3.36 \%$ for polyphenols and $9.54 \%$ for flavonoids indicating a good reproducibility. The modified $R^{2}$ was well within reasonable limits in this study $\left(R^{2} \geq 0.80\right)$, suggesting that the experimental results matched the second order polynomial equations well. ${ }^{23}$

\section{Analysis of response surface}

To better understand the impact of the interaction of the independent variables on the extraction process, $3 \mathrm{D}$ response surface plots and contour plots were developed. These 3D graphs allow for a better understanding of the main and cross effects of the responses on the target of the independent variables. Figure (a-f) shows the effects of varying temperature, incubation time and ethanol concentration on polyphenol and flavonoid assays for the extraction of $S$. nepeta $\mathrm{L}$. extract. Polyphenols and flavonoids content is influenced by extraction method, temperature, incubation time and ethanol concentration. These contents, according to the $3 \mathrm{D}$ plot, first increased and then decreased with increasing ethanol concentrations; the same results were reported by. ${ }^{24}$ The TPC and TFC values were highest when the 


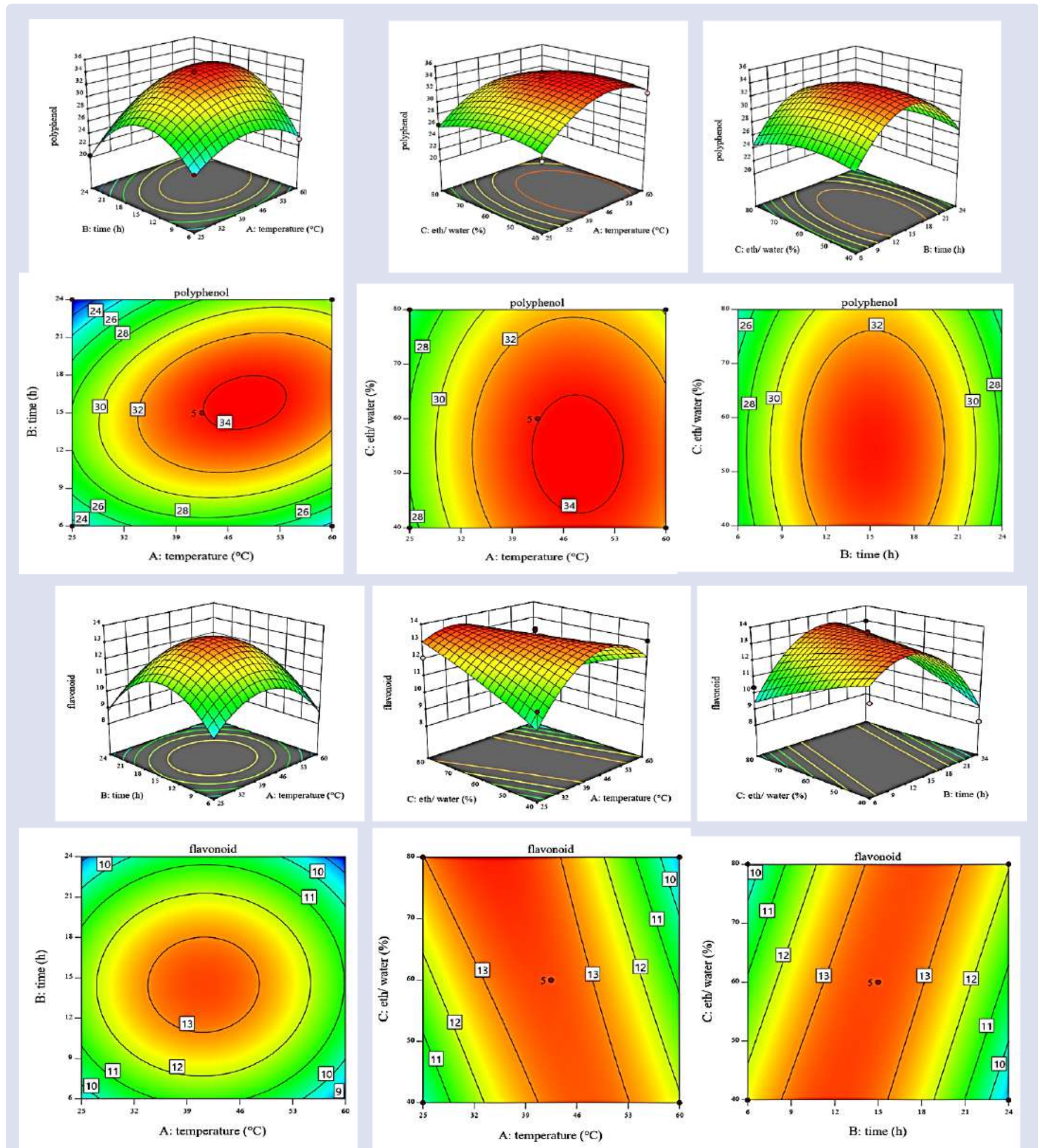

Figure 1: Surface response methodology in different extraction methods of S.nepta show the effect of different extraction parameters (a: temperature; b: extraction time and c: ethanol concentration) on total phenolic content (TPC) (a,b and c) expressed as mg gallic acid equivalents / $\mathrm{g}$ dry plant (mg GAE / $\mathrm{g}$ ) and total flavonoids (TFC) (e, fand g) expressed as mg quercetin equivalents / $g$ dry plant (mg QE / g). 
extraction was performed with a temperature of 25 to $42.5^{\circ} \mathrm{C}$. While, the extracts obtained with the temperature $60{ }^{\circ} \mathrm{C}$ had the lowest TPC and TFC values. The maximum predicted site of TPC $(33.96 \pm 1.89$ $\mathrm{mg}$ TAE/g extract) and TFC (13.73 $\pm 0.183 \mathrm{mg}$ QE/g extract) was obtained under the optimum extraction conditions of $60 \%$ ethanol concentration, $15 \mathrm{~h}$ extraction time and temperature $42.5^{\circ} \mathrm{C}$. The decrease in the content of these with increasing extraction time and temperature can be attributed to the increase in contact time between the solvent (ethanol) and the sample and the effect also of temperatures which leads to the degradation of these compounds. ${ }^{22}$ The interaction effect of the solvent/extraction ratio couple plays an important role in the extraction, influencing the content of polyphenols and flavonoids, ${ }^{25}$ the ethanol/water ratio has a positive influence on the content but decreases after a high volume of the solvent. According to these results, the effect of independent variables and their interactions were statistically significant at $95 \%$ confidence level.

\section{Extract yield, total phenolics, tannins and flavonoids content}

The yields of the infusion extract, decoction and hydroalcoholic extract were $21.09 \%, 18.44 \%$ and $9 \%$, respectively. The yield recorded in our study is higher than that found in other Lamiaceae studies ${ }^{26}$ and lower than Algerian Calamintha nepeta L. ${ }^{27}$ The results of polyphenols quantification, showed that the infused extract of $S$. nepeta L. (Table $3)$ has the highest TPC $(66 \pm 1.682 \mathrm{mg}$ TAE/g extract), TFC $(21.81 \pm 0.1$ $\mathrm{mg} \mathrm{QE} / \mathrm{g}$ extract) and tannins ( $17 \pm 0.14 \mathrm{mg} \mathrm{GAE} / \mathrm{g}$ extract) followed by the decoction extract. The hydroethanolic extract shows polyphenol levels $(34.09 \pm 1.89 \mathrm{mg} \mathrm{TAE} / \mathrm{g}$ extract) twice lower than the infused extract. The flavonoids and tannins contents were twice and four times lower, respectively than the infused extract. The present results are in agreement with other study ${ }^{27}$ focusing on the same species of Algerian Satureja Calamintha nepeta L., concerning the infused and decocted extract. TPC and TFC evaluated by Gomes $e$ t al. With the same methods for the three Satureja species ethanolic extracts are widely lower than our results. This difference in polyphenol and flavonoid levels could be explained by the difference in sample pretreatment (degreasing and size reduction) and the conditions of the extraction process (solvent/ sample ratio, incubation time and extraction temperature) ${ }^{28}$

\section{Chemical composition of extracts and EO}

Results of HPLC-UV and CG-MS of decoction, infusion, hydroalcoholic extracts and EO are presented respectively in (tables 4 and 5), the compounds were identified by comparison of retention times and spectral characteristics with standard reference compounds. UV spectrum analysis of the main peaks indicated that the compounds belonged to the phenol group. Hence, we compared our results with standard water-soluble polyphenols commonly found in Lamiaceae species and/or other plants as reported (Alice et al., 2019). The phenolic profile of $S$. nepeta L., obtained after decoction is characterized and provisionally identified are presented in table 4 . Among compounds detected, seven of which were Gallic acid, Caffeic acid, Syringic acid, Ferulic acid, Catechin, Caffeic and Rutin. The compounds eluted at 1.19 and $24.06 \mathrm{~min}$ for the infusion extract were identified as Quercetine, Gallic acid, Syringic acid, p-coumaric acid, Ferulic acid, Vanillic acid, Catechin, Rutin and Vanillin. Also, the hydroalcoholic extract with five compounds were identified as Quercetine, Gallic acid, Caffeic acid, Syringic acid and Rutin. In the same species Satureja, Caffeic has been identified in the infusion extract but not in the decoction one ${ }^{27}$, however, Moroccan S.nepeta L. presents Caffeic in these two extracts. Moreover, Rutin has been identified in the three extracts of the Moroccan plant, unlike Algerian Satureja where it is completely absent. ${ }^{27}$ This difference in the chemical composition of the extracts may strongly be influences by biotic and abiotic factors. It depends on climatic, seasonal and geographical conditions as well as the harvesting period of the plant to regulate the extraction techniques. ${ }^{30}$ Rutin a glycoside, belonging to flavonoids, is found in many plants and fruits. It has been shown to have an extensive array of pharmacological applications due to its numerous properties (Singh et al., 2019), Syringic acid is widely known as natural antioxidant in several studies, and are distributed in several

Table 3: Total content of phenolic, tannin and flavonoid components for the three extracts.

$\begin{array}{lccc} & \begin{array}{c}\text { Phenolic content } \\ \text { (mg TAE/g } \\ \text { extract) }\end{array} & \begin{array}{c}\text { Flavonoid content } \\ \text { (mg QE/g } \\ \text { extract) }\end{array} & \begin{array}{c}\text { Tannin content } \\ \text { (mg GAE/g } \\ \text { extract) }\end{array} \\ \begin{array}{l}\text { Decoction } \\ \text { extract }\end{array} & 42.53 \pm 0.896^{\mathrm{b}} & 15.37 \pm 0.038^{\mathrm{b}} & 11.25 \pm 0.096^{\mathrm{b}} \\ \begin{array}{l}\text { Infusion } \\ \text { extract }\end{array} & 66 \pm 1.682^{\mathrm{a}} & 21,81 \pm 0.1^{\mathrm{a}} & 17 \pm 0.14^{\mathrm{a}} \\ \text { Hydroalcoholic extract } & 34.09 \pm 1.89^{\mathrm{c}} & 13.73 \pm 0.183^{\mathrm{c}} & 4.32 \pm 0.03^{\mathrm{c}}\end{array}$

All the values are mean of triplicate determination \pm SD; SD: standard deviation

a-c Column wise values with different superscripts of this type indicate significant difference $(p<0.05)$

Table 4: Retention time (Rt) and identification of phenolic compounds in and infusion, decoction and hydroalcoholic extracts of Satureja nepeta L.

\begin{tabular}{|c|c|c|c|c|c|c|}
\hline \multirow{2}{*}{$\begin{array}{l}\text { The phenolic } \\
\text { standards }\end{array}$} & \multirow{2}{*}{$\begin{array}{l}\text { Retention time } \\
\text { (min) }\end{array}$} & \multirow{2}{*}{ MolecularWeight } & \multirow{2}{*}{ Formula } & \multicolumn{3}{|c|}{ Detected polyphenols for the extracts } \\
\hline & & & & Decoction & Infusion & Hydroalcoholic \\
\hline Quercétine & 1.19 & 448 & $\mathrm{C}_{21} \mathrm{H}_{20} \mathrm{O}_{11}$ & - & + & + \\
\hline Gallicacid & 2.27 & 170 & $\mathrm{C}_{7} \mathrm{H}_{6} \mathrm{O}_{5}$ & + & + & + \\
\hline Caffeicacid & 3.05 & 180 & $\mathrm{C}_{9} \mathrm{H}_{8} \mathrm{O}_{4}$ & + & - & + \\
\hline Syringicacid & 4.75 & 198 & $\mathrm{C}_{9} \mathrm{H}_{10} \mathrm{O}_{5}$ & + & + & + \\
\hline p-coumaricacid & 7.08 & 164 & $\mathrm{C}_{9} \mathrm{H}_{7} \mathrm{O}_{3}$ & - & + & - \\
\hline Ferulicacid & 7.57 & 194 & $\mathrm{C}_{10} \mathrm{H}_{10} \mathrm{O}_{4}$ & + & + & - \\
\hline Vanillicacid & 8.44 & 168 & $\mathrm{C}_{8} \mathrm{H}_{8} \mathrm{O}_{4}$ & - & + & - \\
\hline Catechin & 9.10 & 291 & $\mathrm{C}_{15} \mathrm{H}_{14} \mathrm{O}_{6}$ & + & + & - \\
\hline Caffeic & 9.60 & 180 & $\mathrm{C}_{9} \mathrm{H}_{8} \mathrm{O}_{4}$ & + & - & - \\
\hline Rutin & 23.33 & 610 & $\mathrm{C}_{27} \mathrm{H}_{30} \mathrm{O}_{16}$ & + & + & + \\
\hline Vanillin & 24.06 & 151 & $\mathrm{C}_{8} \mathrm{H}_{8} \mathrm{O}_{3}$ & - & + & - \\
\hline
\end{tabular}


species of Lamiaceae, including Clinopodium vulgarecompris and Origanunheracleoticum. ${ }^{32,33}$ Table 5 shows the results of the GC-MS analyzes; the compounds are listed in the order of their elution time. A total of 19 components were identified where $\alpha$-Pinene $(58.96 \%)$ and Carvacrol (20.67 \%) were the two major compounds, while others compounds were detected at low concentration, namely a Thujene (7.36 $\%)$, Thuja-2,4(10)-diene (2.24\%), and Thymol (2.15\%). Several studies have shown that Carvacrol and $\alpha$-Pinene were the major compounds in other species of Saturej, ${ }^{34,35}$ but in indifferent proportions while other studies have revealed different main compounds. ${ }^{5}$ Different environmental and genetic factors, chemotypes, and the nutritional status of the plants can all contribute to the observed differences in the constituents of basil EO across countries. ${ }^{36,37}$

\section{Antioxidant activities of S. nepeta L. extracts and EO}

There is a great variety of in vitro methods to assess radical scavenging ability and determine the antioxidant activity of plant extracts and EO. In this study, three antioxidant assays were carried out for $S$. nepeta L., the power reduction test to measure the reducing power, DPPH and ABTS for the evaluation of free radical scavenging activity, compared to those of ascorbic acid standard and BHT. Table 6 shows the results obtained for antioxidant activities. Usually, all preparations revealed antioxidant potential, namely reducing power, free radical scavenging activity.

\section{Scavenging activity towards Ferric-Reducing}

The power reduction results are expressed in $\mathrm{EC}_{50}$ values (table 6). The reduction in the potency of the extracts compared to the positive control (ascorbic acid and BHT) varied significantly $(\mathrm{p}<0.05)$ in different extraction method (decoction, infusion and hydroalcoholic and EO). The activities of the samples ranged from 0.26 to $0.56 \mathrm{mg} /$ $\mathrm{mL}$ while $\mathrm{EO}\left(\mathrm{EC}_{50}=3.25 \pm 0.09 \mathrm{mg} / \mathrm{mL}\right)$, the reducing capacities of the extracts were almost nine times higher than $\mathrm{EO}$, this may be due to the low content of antioxidant constituents for EO which can be susceptible to degradation by temperature. According to some studies, free radical reducing capacities depend on the structural conformation of phenolic compounds. ${ }^{38}$

\section{Scavenging activity towards DPPH'}

$\mathrm{IC}_{50}$ was calculated as the amount of antioxidant present in the sample needed to reduce the initial concentration of DPPH from $50 \%$. The lower the $\mathrm{IC}_{50}$ value showed the higher antioxidant activity. All extracts of $S$. nepeta L., revealed free radical scavenging activity. Compared $\mathrm{IC}_{50}$ values of each sample, with ascorbic acid and BHT as a positive control, showed that the order of DPPH scavenging ability was BHT $>$ Ascorbic Acid > infusion $>$ decoction $>$ hydroalcoholic $>$ EO (Table 6). Among the extracts, the infusion preparation showed the most powerful scavenging activity of the DPPH radical $0.41 \pm 0.04$ $\mathrm{mg} / \mathrm{mL}$, whereas, the hydroalcoholic extract exhibited a much lower antioxidant activity with the highest $\mathrm{IC}_{50}$ value $0.68 \pm 0.03 \mathrm{mg} / \mathrm{mL}$. The antioxidant activities of $S$. nepeta $\mathrm{L}$. are related to the amount of phenolic compounds. Extracts with high antioxidant activity seem to be correlated with the presence of significant levels of soluble phenolic compounds. Several reports have shown a correlation between TPC and high antioxidant activity. ${ }^{39}$

Table 5: Chemical composition of Satureja nepeta essential oil.

\begin{tabular}{|c|c|c|c|c|}
\hline Peak & $\begin{array}{l}\text { Kovats index } \\
\text { (KI) }\end{array}$ & Retention time (min) & $\begin{array}{c}\text { Composition } \\
(\%)\end{array}$ & Compounds \\
\hline 1 & 801 & 3.41 & 1.82 & Octane \\
\hline 2 & 845 & 3.48 & 1.91 & Salvene \\
\hline 3 & 850 & 3.52 & 0.52 & (2E)-hexanal \\
\hline 4 & 863 & 3.61 & 0.21 & sabinene \\
\hline 5 & 880 & 3.64 & 0.59 & Allyl butanoate \\
\hline 6 & 887 & 3.65 & 0.12 & Myrcene \\
\hline 7 & 903 & 3.71 & 0.25 & n-heptanal \\
\hline 8 & 916 & 3.79 & 0.21 & tricyclene \\
\hline 9 & 924 & 3.84 & 7.36 & a Thujene \\
\hline 10 & 946 & 4.24 & 0.45 & Camphene \\
\hline 11 & 959 & 4.32 & 58.96 & a-Pinene \\
\hline 12 & 1026 & 4.42 & 2.24 & Thuja-2,4(10)-diene \\
\hline 13 & 1037 & 4.62 & 1.05 & Limonene \\
\hline 14 & 1286 & 4.75 & 0.36 & cis-b-Ocimene \\
\hline 15 & 1290 & 4.86 & 20.67 & Carvacrol \\
\hline 16 & 1295 & 4.97 & 2.15 & Thymol \\
\hline 17 & 1374 & 5.05 & 0.16 & $a$-Copaene \\
\hline 18 & 1387 & 5.34 & 0.14 & $\beta$-Bourbonene \\
\hline 19 & 1481 & 6.06 & 0.39 & Germacrene D \\
\hline
\end{tabular}

Table 6: Antioxidant activity of infusion, decoction, hydroalcoholic extracts and EO of Satureja nepeta L.

\begin{tabular}{|c|c|c|c|}
\hline & $\begin{array}{l}\text { Reducing power } \\
\left(\mathrm{EC}_{50}, \mathrm{mg} / \mathrm{mL}\right)\end{array}$ & $\begin{array}{c}\text { DPPH } \\
\left(\mathrm{IC}_{50}, \mathrm{mg} / \mathrm{mL}\right)\end{array}$ & $\begin{array}{c}\text { ABTS } \\
\left(\mathrm{IC}_{50^{\prime}} \mathrm{mg} / \mathrm{mL}\right)\end{array}$ \\
\hline Decoction & $0.34 \pm 0.12^{\mathrm{b}}$ & $0,5 \pm 0.06^{b}$ & $0.78 \pm 0.02^{\mathrm{b}}$ \\
\hline Infusion & $0.26 \pm 0.08^{c}$ & $0,41 \pm 0.04^{\mathrm{c}}$ & $0,63 \pm 0.08^{c}$ \\
\hline Hydroalcoholic extract & $0.56 \pm 0.04^{\mathrm{a}}$ & $0.68 \pm 0.03^{\mathrm{a}}$ & $0.95 \pm 0.06^{\mathrm{a}}$ \\
\hline Essential oils & $3.25 \pm 0.09^{\mathrm{a}}$ & $1.23 \pm 0.37^{\mathrm{a}}$ & $1.98 \pm 0.37^{\mathrm{a}}$ \\
\hline Ascorbic acid & $0.023 \pm 0.1^{\mathrm{d}}$ & $0.013 \pm 0.01^{\mathrm{d}}$ & $0.032 \pm 0.03^{\mathrm{d}}$ \\
\hline BHT & $0.012 \pm 0.08^{d}$ & $0.04 \pm 0.067^{\mathrm{d}}$ & $0.018 \pm 0.042^{\mathrm{d}}$ \\
\hline
\end{tabular}

All the values are mean \pm SD; SD: standard deviation.

a-d Column wise values with different superscripts of this type indicate significant difference $(p<0.05)$. 


\section{Scavenging activity toward ABTS+}

The measurement of antioxidant activity with ABTS tests are fast, sensitive and more frequently applied for the preliminary assessment of the antioxidant potential of various natural substances. Although the basic principles are similar, the ABTS test is preferable for its activity to evaluate the antioxidant activity of lipophilic and hydrophilic antioxidants. Table 6 shows that all extracts and EO have moderate antioxidant activity. The infused extract has the lowest $\mathrm{IC}_{50}(0.63 \pm 0.08$ $\mathrm{mg} / \mathrm{mL}$ ), thus the highest antioxidant activity compared to the decocted extract $(0.78 \pm 0.02 \mathrm{mg} / \mathrm{mL})$, hydroalcoholic extract $(0.95 \pm 0.06 \mathrm{mg} / \mathrm{mL})$ and $\mathrm{EO}(1.98 \pm 0.37 \mathrm{mg} / \mathrm{mL})$, these values are significantly lower than the given antioxidant value of the positive controls (ascorbic acid and BHT), $(0.032 \pm 0.03 \mathrm{mg} / \mathrm{mL})$ and $(0.018 \pm 0.042 \mathrm{mg} / \mathrm{mL})$, respectively. So, the inhibition rate increases with increasing concentrations of polyphenols in samples.

These differences between ABTS, DPPH and reducing power data for the same samples could be explained by differences in solvent polarity that affect the main electron transfer mechanisms, this means that the radical cation is reactive towards most antioxidants and is soluble in aqueous and organic solvents. Moreover, it can be applied over a wide range of $\mathrm{pH}$ and/or ionic strength. The DPPH test is mainly based on the electron transfer reaction and the interactions between antioxidantDPPH radicals are also determined by the structural conformation of antioxidants. ${ }^{40}$

The statistical study of the results of the antioxidant tests (reduction of the trapping of the free radical DPPH, iron reducing power test and the ABTS $^{+}$radical reduction test) shows significant differences $(p<0.05)$ between the $\mathrm{IC}_{50}$ values for the different antioxidant tests performed on S. nepeta L.. As expected, an excellent correlation has been observed between DPPH and ABTS.+, results showed that the aqueous extract is still more effective at scavenging free radicals than the hydro-ethanoic extract. This is due to the similarity of both methods that measure the ability of antioxidants to give a hydrogen atom. Lower $\mathrm{IC}_{50}$ values are observed for DPPH tests (Table 6) probably due to redox potential differences, in reaction of stoichiometry and / or steric effect of the two radicals, depending on the compounds of the extract involved. ${ }^{41}$ Most studies explain the variation of the antioxidant potential according to the extraction solvents, therefore according to their polarity. ${ }^{42}$ Indeed, the extraction solvent used, not only influenced the yields of total phenols, but also the antioxidant activities of the extracts. ${ }^{43}$ Flavonoids combine with metal ions and form a chelating complex, and can easily oxidize and give electrons to trap free radicals. It has also been reported that the flavonoid component and the antioxidant activity have a linear correlation. ${ }^{44}$ The extraction time of the polyphenols has a significant effect mainly on antioxidant activities where longer extraction times have better efficiency. ${ }^{43}$

\section{CONCLUSION}

The bioactive constituents of $S$. nepeta have aroused the interest of scientists who seek to prevent disease and promote health. In this context, the present study has for the first time identified and referenced a Moroccan plant of the genus Satureja, S. nepeta L., and carried out a characterization of the polyphenol content, as well as the antioxidant activities of decoction, infusion and hydroalcoholic extracts and EO.

The infusion extract of $S$. nepeta $\mathrm{L}$. showed the highest level of phenolic compounds. The polyphenol composition of the extracts and the characterization of the EO were determined by HPLC-UV and GCMS, respectively. This has allowed to identify some molecules among the different extracts and EO. Samples tested showed an antioxidant potential, especially free radical scavenging activity, primarily due to their polyphenol content.
The results of this study will support the use of $S$. nepeta $\mathrm{L}$. in a balanced diet. Indeed, a diet enriched with $S$. nepeta rich in polyphenolic compounds would be beneficial for enhanced microbiota diversity which can enhance intestinal homeostasis.

\section{REFERENCES}

1. Curutchet A, Dellacassa E, Ringuelet JA, Chaves AR, Viña SZ Nutritional and sensory quality during refrigerated storage of fresh-cut mints (Mentha\$limes\$ piperita and M. spicata). Food chemistry. 2014;143:231-8.

2. Kaya A, Satil F, Gogel F. Nutlet surface micromorphology of Turkish Satureja (Lamiaceae). Biologia. 2009;64:902-7.

3. Baba Aissa F. Encyclopédie des plantes utiles, flore d'Algérie et du Maghreb, substances végétales d'Afrique, d'Orient et d'Occident. Ed Librairie moderne Rouiba. 2000;46.

4. Bessedik Z, Bahri B. Evaluation de L'effet insecticide de l'extrait méthanoique et les huiles essentielles des feuilles de Calamintha nepeta vis-à-vis des puceronsdes agrumes. 2018.

5. Tepe B, Cilkiz M. A pharmacological and phytochemical overview on Satureja. Pharmaceutical biology. 2016;54:375-412.

6. Hooda A, Nanda A, Jain M, Kumar V, Rathee P. Optimization and evaluation of gastroretentive ranitidine $\mathrm{HCl}$ microspheres by using design expert software. International journal of biological macromolecules. 2012;51:691-700.

7. Toubane A, Rezzoug SA, Besombes C, Daoud K. Optimization of Accelerated Solvent Extraction of Carthamus Caeruleus L. Evaluation of antioxidant and anti-inflammatory activity of extracts. Industrial Crops and Products. 2017;97:620-31.

8. Bousbia N, Vian MA, Ferhat MA, Petitcolas E, Meklati BY, Chemat F. Comparison of two isolation methods for essential oil from rosemary leaves: Hydrodistillation and microwave hydrodiffusion and gravity. Food chemistry. 2009;114:355-62.

9. Coppin JP, Xu Y, Chen H, Pan M-H, Ho C-T, Juliani R, et al. Determination of flavonoids by LC/MS and anti-inflammatory activity in Moringaoleifera. Journal of Functional Foods. 2013;5:1892-9.

10. Liu H, Cao J, Jiang W. Evaluation and comparison of vitamin C, phenolic compounds, antioxidant properties and metal chelating activity of pulp and peel from selected peach cultivars. LWT-Food Science and Technology. 2015;63:1042-8.

11. Zhou K, Yin J-J, Yu LL. ESR determination of the reactions between selected phenolic acids and free radicals or transition metals. Food Chemistry. 2006;95:446-57.

12. Alam MS, Stark C, Harrison RM. Using variable ionization energy time-of-flight mass spectrometry with comprehensive GC\$ times\$ GC to identify isomeric species. Analytical chemistry. 2016;88:4211-20

13. Dorman HD, Koşar M, Kahlos K, Holm Y, Hiltunen R. Antioxidant properties and composition of aqueous extracts from Mentha species, hybrids, varieties, and cultivars. Journal of agricultural and food chemistry. 2003;51:4563-9.

14. Ahn M-R, Kumazawa S, UsuiY, Nakamura J, Matsuka M, Zhu F, et al. Antioxidant activity and constituents of propolis collected in various areas of China. Food Chemistry. 2007;101:1383-92.

15. Tambe VD, Bhambar RS. Estimation of total phenol, tannin, alkaloid and flavonoid in Hibiscus tiliaceus Linn. wood extracts. Journal of pharmacognosy and phytochemistry. 2014;2:41-7.

16. Oyaizu M. Studies on products of browning reaction. The Japanese journal of nutrition and dietetics. 1986;44:307-15.

17. Brand-Williams W, Cuvelier M-E, Berset C. Use of a free radical method to evaluate antioxidant activity. LWT-Food science and Technology. 1995;28:25-30. 
18. Szlachta M, Malecka M. Wlasciwosciprzeciwutleniajaceherbatekowocowych. ŻywnośćNaukaTechnologiaJakość. 2008;15:92-102.

19. Wang L, Bei Q, Wu Y, Liao W, Wu Z. Characterization of soluble and insoluble-bound polyphenols from Psidiumguajava L. leaves co-fermented with Monascusanka and Bacillus sp. and their bioactivities. Journal of Functional Foods. 2017;32:149-59.

20. Dent $M$, Dragović-Uzelac V, Penić $M$, Bosiljkov T, Levaj B. The effect of extraction solvents, temperature and time on the composition and mass fraction of polyphenols in Dalmatian wild sage (Salvia officinalis L.) extracts. Food technology and biotechnology. 2013;51:84-91.

21. Mokrani A, Madani K. Effect of solvent, time and temperature on the extraction of phenolic compounds and antioxidant capacity of peach (Prunuspersica L.) fruit. Separation and Purification Technology. 2016;162:68-76.

22. Ciric A, Krajnc B, Heath D, Ogrinc N. Response surface methodology and artificial neural network approach for the optimization of ultrasound-assisted extraction of polyphenols from garlic. Food and Chemical Toxicology. 2020;135:110976.

23. Leardi R. Experimental design in chemistry: A tutorial. Analyticachimicaacta. 2009;652:161-72.

24. Esmaeelian M, Jahani M, Feizy J, Einafshar S. Effects of UltrasoundAssisted and Direct Solvent Extraction Methods on the Antioxidant and Antibacterial Properties of Saffron (Crocus sativus L.) Corm Extract. Food Analytical Methods. 2021;14:74-87.

25. Galan A-M, Calinescu I, Trifan A, Winkworth-Smith C, CalvoCarrascal M, Dodds C, et al. New insights into the role of selective and volumetric heating during microwave extraction: Investigation of the extraction of polyphenolic compounds from sea buckthorn leaves using microwave-assisted extraction and conventional solvent extraction. Chemical Engineering and Processing: Process Intensification. 2017:116:29-39.

26. Martins N, Barros L, Santos-Buelga C, Henriques M, Silva S, Ferreira ICFR. Evaluation of bioactive properties and phenolic compounds in different extracts prepared from Salvia officinalis L. Food Chemistry. 2015; 170:378-85

27. Khodja NK, Boulekbache L, Chegdani F, Dahmani K, Bennis F, Madani K. Chemical composition and antioxidant activity of phenolic compounds and essential oils from Calamintha nepeta L. Journal of Complementary and Integrative Medicine. 2018;15.

28. Hammami $\mathrm{H}$, Yazidi O, Ben El HadjRhouma M, Al Mogren MM, Hochlaf M. Theoretical investigations of the $10, q+(q=2,3,4)$ multicharged ions: Metastability, characterization and spectroscopy. J Chem Phys. 2014;141:014302.

29. Alice G, Corina B, Lucia P, Sultana N, Bazdoaca C, Nicoleta D. Polyphenol Content Dynamics in Hydrodistillation Water Residues of Lamiaceae Species. Journal of Essential Oil Bearing Plants. 2019;1-7.

30. Kaplan M, YILMAZ MM, Rabia U, Köprü S, Gözelle H, Muhderem G. An Optimization Study for The Production of Origanumonites Tincture by Response Surface Methodology: Effect of Solid/ Liquid Ratio, Ethanol Concentration and Storage Period. TekirdağZiraatFakültesiDergisi. 2019;16:11-22.

31. Singh S, Singh DR, Banu VS, Singh LB. Determination of functional constituents (Phytochemicals, micronutrients), anti-nutrients and antioxidant activity in commonly grown genotypes of Basella L. IJCS. 2019;7:403-9
32. Janicsák G, Máthé I, Miklóssy-Vári V, Blunden G. Comparative studies of the rosmarinic and caffeic acid contents of Lamiaceae species. Biochemical Systematics and Ecology. 1999;27:733-8.

33. Xu P, Chen L, Wang Y. Effect of storage time on antioxidant activity and inhibition on $\alpha$-Amylase and $\alpha$-Glucosidase of white tea. Food science \& nutrition. 2019;7:636-44

34. Hadian J, Esmaeili $H$, Nadjafi F, Khadivi-Khub A. Essential oil characterization of Satureja rechingeri in Iran. Industrial crops and products. 2014;61:403-9.

35. Mazarei Z, Rafati H. Nanoemulsification of Satureja khuzestanica essential oil and pure carvacrol; comparison of physicochemical properties and antimicrobial activity against food pathogens. LWT. 2019;100:328-34

36. Naitlrahal I, azzahra Lahlou F, Hmimid F, Errami A, Guenaou I, Diawara I, et al. Identification of the chemical composition of six essential oils with mass spectroscopy and evaluation of their antibacterial and antioxidant potential. Flavour and Fragrance Journal. 2021.

37. Luz TRSA, Leite JAC, de Mesquita LSS, Bezerra SA, Silveira DPB, de Mesquita JWC, et al. Seasonal variation in the chemical composition and biological activity of the essential oil of Mesosphaerumsuaveolens (L.) Kuntze. Industrial crops and products. 2020;153:112600.

38. Han F, Ma G, Yang M, Yan L, Xiong W, Shu J, et al. Chemical composition and antioxidant activities of essential oils from different parts of the oregano. Journal of Zhejiang University-Science B. 2017:18:79-84.

39. Serrano C, Matos O, Teixeira B, Ramos C, Neng N, Nogueira J, et al. Antioxidant and antimicrobial activity of Satureja montana L. extracts. Journal of the Science of Food and Agriculture. 2011;91:1554-60.

40. Martysiak-Żurowska D, Wenta W. A comparison of ABTS and DPPH methods for assessing the total antioxidant capacity of human milk. Actascientiarumpolonorumtechnologiaalimentaria. 2012;11:83-9.

41. Mojab F, Nickavar B. Composition of the Essential Oil of the Root of Heracleumpersicum from Iran. Iranian Journal of Pharmaceutical Research. 2010;0:245-7.

42. Kobus-Cisowska J, Szczepaniak O, Szymanowska-Powalowska D, Piechocka J, Szulc P, Dziedziński M. Antioxidant potential of various solvent extract from Morus alba fruits and its major polyphenols composition. Ciência Rural. 2020;50.

43. Alonso-Carrillo N, Aguilar-Santamaría Ma de los Á, Vernon-Carter EJ, Jiménez-Alvarado R, Cruz-Sosa F, Román-Guerrero A. Extraction of phenolic compounds from Satureja macrostema using microwaveultrasound assisted and reflux methods and evaluation of their antioxidant activity and cytotoxicity. Industrial Crops and Products. 2017; 103:213-21

44. Tanleque-Alberto $F$ Juan-Borrás $M$, Escriche I. Antioxidant characteristics of honey from Mozambique based on specific flavonoids and phenolic acid compounds. Journal of Food Composition and Analysis. 2020;86:103377.

45. Garg P, Garg R. Phytochemical screening and quantitative estimation of total flavonoids of Ocimum sanctum in different solvent extract. 2019; 


\section{GRAPHICAL ABSTRACT}

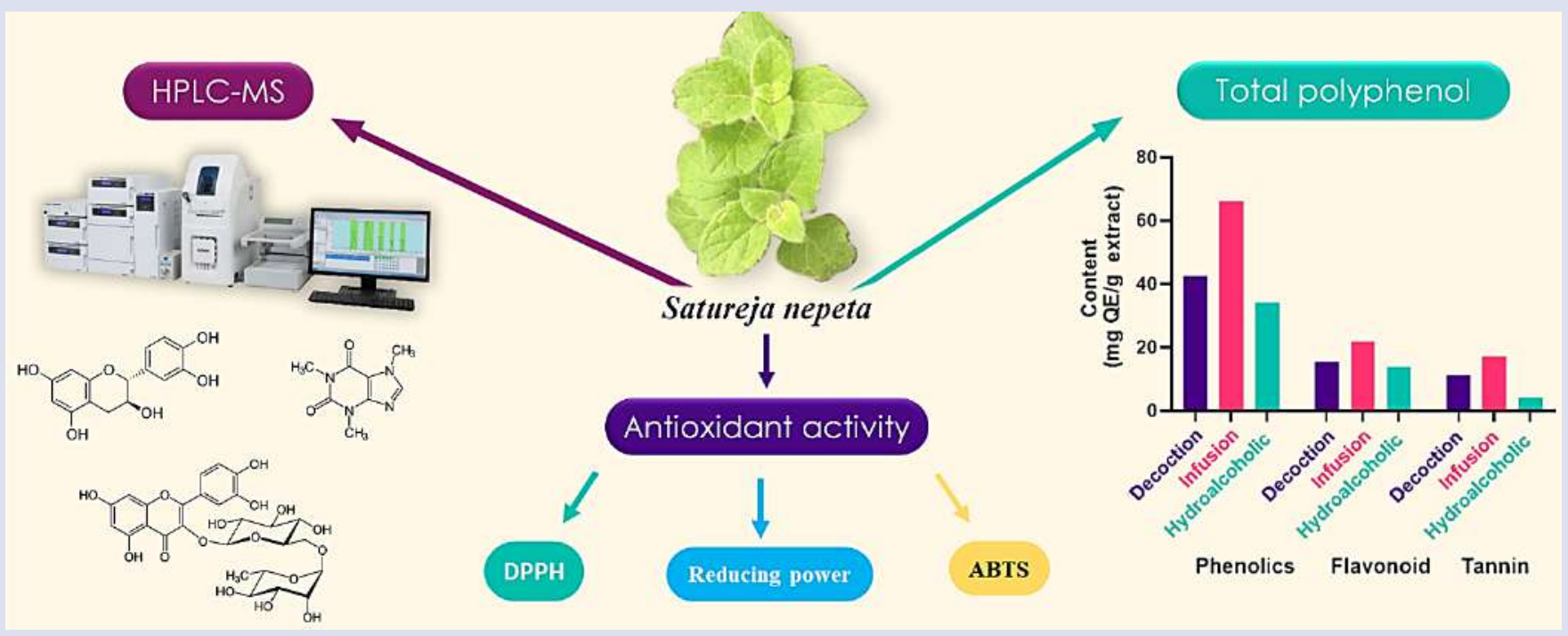

\section{ABOUT AUTHORS}

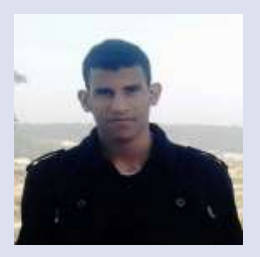

POSITION TITLE: PhD student

ADRESSE: Labortory of Immunology and Biodiversity, Departement of Biology,

Faculty of Sciences Ain Chock, Hassan II University of Casablanca, Route El Jadida BP 5366 Maarif, Casablanca, Morocco

표라.: +212649533839 Fax: +212522 230674

ezaouine.abdelkarim@gmail.com

\section{FIELD OF COMPETENCE: MOLECULAR BIOLOGY AND BIOINFORMATICS} POSITION AND EMPLOYEMENT

PhD Student at the Ain Chock Faculty of Sciences, Hassan II University, Casablanca, since 2018. Research topic: Host-microbiota interactions and biochemistry POSITION TITLE: PhD student

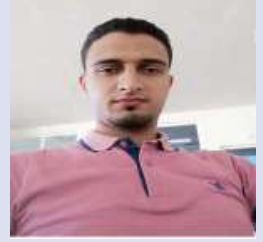

ADRESSE: Labortory of Immunology and Biodiversity, Departement of Biology,

Faculty of Sciences Aïn Chock, Hassan II University of Casablanca, Route EI Jadida BP 5366 Maarif, Casablanca, Morocco

푤el.: 0522230680 Fax: 0522230674.

ridasalam9@gmail.com

\section{FIELD OF COMPETENCE: MOLECULAR BIOLOGY AND BIOINFORMATICS}

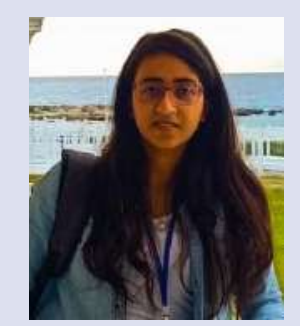

POSITION TITLE: PhD Student

ADRESSE: Labortory of Immunology and Biodiversity, Departement of Biology,

Faculty of Sciences Aï Chock, Hassan II University of Casablanca, Route El Jadida BP 5366Maarif, Casablanca, Morocco

yousra.sbaoui@gmail.com

FIELD OF COMPETENCE: Molecular Biology \& Bioinformatics

POSITION AND EMPLOYEMENT

characterize the distribution of Moroccan marine microbiota in the surface microlayer 


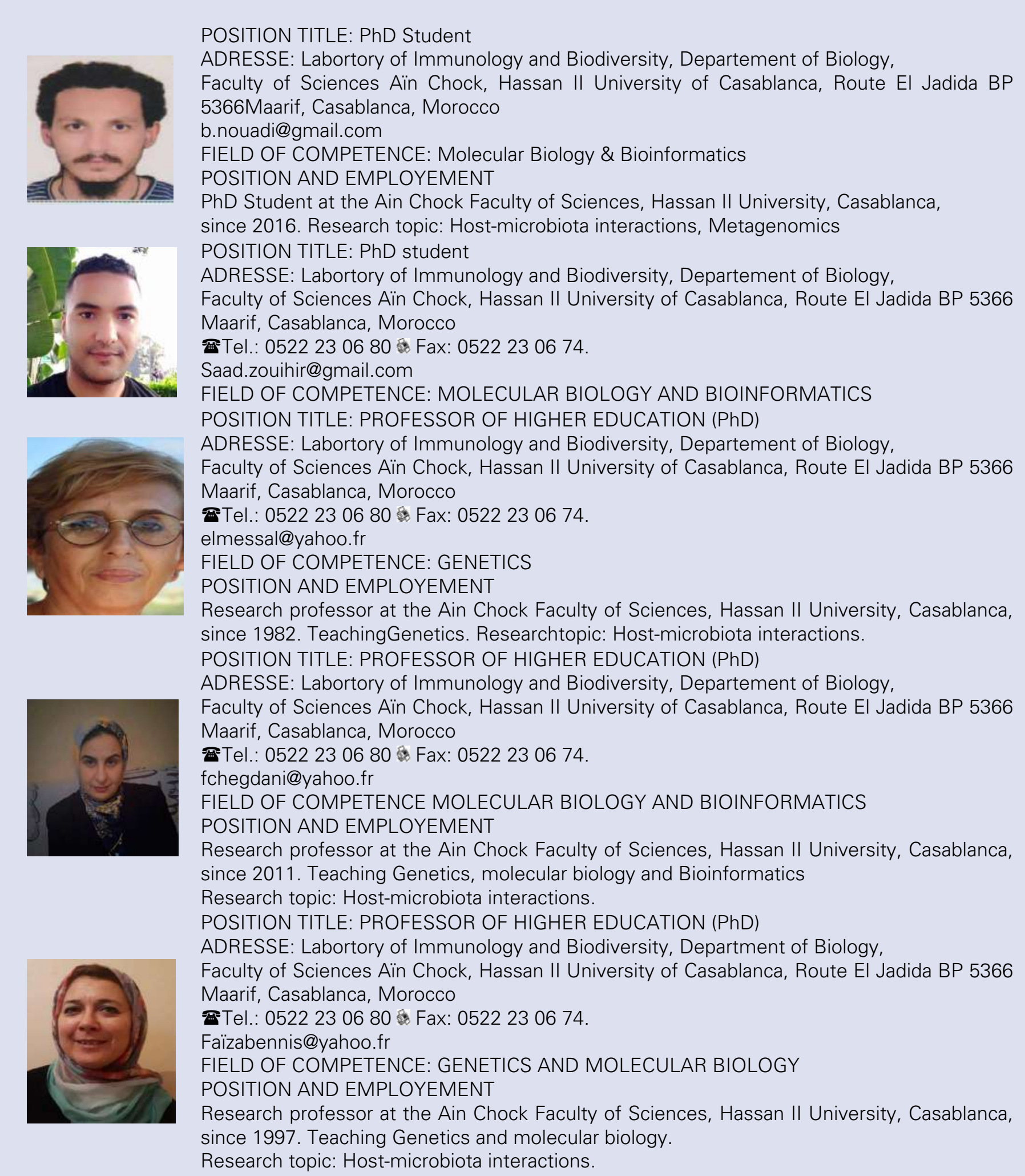
Faculty of Sciences Aïn Chock, Hassan II University of Casablanca, Route El Jadida BP 5366 Maarif, Casablanca, Morocco Faculty of Sciences Ain Chock, Hassan II University of Casablanca, Route El Jadida BP 5366 Maarif, Casablanca, Morocco

Cite this article: A EZAOUINE *, M R SALAM,Y SBAOUI, B NOUADI, S ZOUHIR, M ELMESSAL, et al. Extraction, Chemical Composition and Antioxidant Activity of Phenolic Compounds from Moroccan Satureja nepeta L. Pharmacogn J. 2022;14(1): 182192. 